\title{
CHALLENGES FACED BY STUDENTS IN STUDYING TARKÎB WITH ZOOM PLATFORM DURING PANDEMIC
}

\author{
Siti Muflichah ${ }^{1}$, Ridha Darmawaty ${ }^{2}$, Puji Sri Rahayu ${ }^{3}$ \\ ${ }^{12}$ Universitas Islam Negeri Antasari Banjarmasin, Indonesia \\ Jl. A. Yani Km. 4.5 Kel. Kebun Bunga, Banjarmasin, Kalimantan Selatan, 70235, Indonesia \\ ${ }^{3}$ University of Canberra, Australia \\ 11 Kirinari St, Bruce ACT 2617, Australia \\ CorrespondingE-mail: sitimuflichab@uin-antasari.ac.id
}

\begin{abstract}
This paper discusses the difficulties of Arabic department students when dealing with Tarkîb al-Marfü'ât subject and the using of Zoom/forced technology due to the Covid-19 pandemic. Using the qualitative approach, this paper aimed to explore whether students were negatively impacted by switch of learning mode to online. Interviews were conducted to nine students who live in remote areas, and it revealed that those students experienced delay in learning the subject due to their lack of the internet availability. Teaching activities were not optimal due to signal interference so that the exposure to the relevant material was not comprehensive. Moreover the students also lacked understanding to the subject because of the specific difficulty level of the subject. The students missed additional explanations and material from the lecturer, even equipped examples. This paper contributes to educational policies in the ways Indonesian government addresses distance learning for students in Islamic higher education.
\end{abstract}

Keywords: online learning challenges, tarkîb al-marfû̀ ât, zoom platform

\section{Introduction}

There are studies focuses on online learning. For instance, a study by Dwiono, Rochsantiningsih and Suparno ${ }^{1}$ has focused on the significance of educators who have capability on instructing Information Communication Technology/ICT incorporation.

${ }^{1}$ Rija Dwionoa, Dewi Rochsatiningsih, and Suparno, "Investigating the Integration Level of Information and Communication Technology (ICT) in the English Language Teaching", International Journal of Language Teaching and Education, Vol. 2, No. 3, 2018. 


\section{Arabiyât Jurnal Pendidikan Bahasa Arab dan Kebahasaaraban, 8 (2), 2021}

Flewitt, Rossie and Natalia Kucirkova ${ }^{2}$ claim educators need to have ICT skills in order to make interesting learning practices for students. Teachers and instructors need to learn and modify how to manage learning conduct differently as they consolidate ICT in teaching, accordingly aptitudes of teacher is significant here. While Mirzajani, Mahmud, Ayub and Wong ${ }^{3}$ add that instructing in the study has been changed with the coordination of ICT. The utilisation of ICT in the investigation corridor is viewed as a critical procedure to extend the suitability of the teaching learning measure. Researchers recently explored the use of ICT in the classroom.

As we noticed, approximately 1.5 billion students registered worldwide were unable to attend school due to the Covid-19 pandemic as reported by UNESCO ${ }^{4}$. This includes around 45 million Indonesian students or about three percent of the affected global student population. ${ }^{5}$ The Covid-19 pandemic also has an impact on the world of higher education. The existence of this corona virus outbreak hinders teaching and learning activities that usually take place face-to-face. Since mid-March 2020, students have suddenly changed the way they learn. For the most part, it initially used face-to-face dialogic teaching and learning and has become a mode of distance learning.

Indonesian educational institutions started to instruct their students to study online to stop the spread of the virus. Indonesian schools, universities and pondok pesantren (Islamic boarding school) started to shut down. Teachers and lecturers were instructed to work from home, and those institutions were closed for students. The Indonesian government planned to deal with the spread of the virus involved students to use smartphone and required internet access to get online.

This closures and online learning cause challenges as not all schools have online learning systems, most universities have the system but the implementation varies. This circumstance likely contributes to learning setbacks. Moreover, these closures could affect students who depend on their schools and universities' Wi-Fi, as free internet is very rare in Indonesia.

This situation has made difficult to implement online education. When educational institutions closed due to the COVID-19 epidemic, they provide online education to prevent students from falling behind. However, virtual instruction and requiring students to work remotely could not guarantee equal access to technology. ${ }^{6}$ Indonesian government tries to increased access to the internet, but it does not

${ }^{2}$ Rossie Flewitt and Natalia Kucirkova, "Touching the Virtual, touching the real: iPads and enabling literacy for students experiencing disability", Australian Journal of Language and Literacy, Vol. 37 No. 2, 2014.

3 Hassan Mirzajani, Mahmud Rosnaini, Ayub Ahmad Fauzi Mohd, and Su Luan Wong, "Teachers' acceptance of ICT and its integration in the classroom", Quality Assurance in Education, Vol. 24, No. 1, 2016, 26-40.

4 UNESCO, "COVID-19 Educational Disruption and Response", 2020, [online] Available at: https://en.unesco.org/covid19/educationresponse

${ }^{5}$ Badan Pusat Statistik, https://www.bps.go.id/subject/28/pendidikan.html

${ }^{6}$ Dale Mezzacappa and Avi Wolfman-Arent. "Hite clarifies ban on 'remote instruction' during shutdown", Philadelphia Public School Notebook, https://thenotebook.org/articles/2020/03/18/phillyschools-forbid-remote-instruction-during-shutdown-for-equity-concerns/ 2020. 


\section{Arabiyât Jurnal Pendidikan Bahasa Arab dan Kebahasaaraban, 8 (2), 2021}

guarantee that equitable services will be provided to all students. Most students in X University have smartphones, but are more likely to be without a computer or laptop at home. Students, who had no access to computer at home, are still able to join online education but they cannot write their assignments. Further, guaranteeing online access does not mean that equitable services will be provided. For instance, some local districts do not provide free Wi-Fi hotspot and devices to any students in need after closing its schools and university.

No exception, learning at University $\mathrm{X}$ has also experienced a shift. Arabic Department students of the University X also conduct online lectures. Some students who live in urban areas, are generally not constrained by the online model, because the internet may be well available. What about students living in rural areas which are far from cities? This decision to online education can prevent students from experiencing left behind during campus closures. However, some campuses do not have enough resources to provide learning opportunities for students, and not all students have internet access at home. Campuses that implement online learning equitably can improve their approach if they provide a stable internet connection and other supportive means.

In this study, we were eager to investigate how difficult it is for Arabic department students to use technology. We also explore whether the difficulty of using the online platform affects the level of understanding in the TM (Tarkîb alMarfî' $\hat{a} t$ ) course. Lastly, we find out how the students overcome their online learning problems. This is an important topic, because the the participants were students who live in remote areas, where internet access may be very limited.

Arabic as a subject at university has been taught for several decades. As claimed by Fahrurozi, ${ }^{7}$ teaching Arabic in Indonesia often faces linguistic and nonlinguistic problems. Linguistic problems are such as phonetics, morphology, and structure, while non-linguistic problems, among others, are learning motivation, tools, methods, time, and environment. According to Rosyidi ${ }^{8}$ there are some efforts to enhance the quality of Arabic learning. One of them is increasing the teaching language competence. In order to fulfil the competencies expected to be possessed by an Arabic teacher, the institution that prepares prospective Arabic teaching staff, especially for non-native speaker, should pay attention more to Professional aspects, besides linguistic, personality, cultural and social aspects. Professional aspects make a person professional language teacher. A teacher must be equipped with educational sciences such as educational basics, psychology, sociology, learning design, methods, evaluation, and classroom action research. ${ }^{9}$ This aspect may include mastering the skill of ICT. To be a professional, educators have to continuously increase the ICT experiences skills and knowledge to gain and maintain the academic quality.

${ }^{7}$ Aziz Fahrurozi, "Pembelajaran bahasa Arab, problematika dan solusinya", Arabiyat, Vol. 1, No.

8 Abdul Wahab Rosyidi, "Peningkatan Kualitas Pengajar Bahasa Arab Sebagai Upaya Meningkatkan Standar Mutu Pembelajaran Bahasa Arab", Jurnal Ilmiah Peuradeun, Vol. 2, No. 3, 2014.

9 Hamid Darmadi, "Tugas, Peran, Kompetensi, dan Tanggung Jawab Menjadi Guru Profesional", Jurnal Edukasi, Vol. 13, No.2, 2015. 


\section{Arabiyât Jurnal Pendidikan Bahasa Arab dan Kebahasaaraban, 8 (2), 2021}

Pakpahan and Fitriani ${ }^{10}$ find the use of information technology has a very important role in the implementation of distance learning in universities in the midst of the corona virus pandemic covid19. The learning process is effective using information technology and the internet networks connect lecturers and students so that the teaching and learning process succeeds despite the COVID-19 pandemic. Thus, students can improve the Arabic accomplishments if educators implement the ICT in the classroom. Pannen ${ }^{11}$ defines technology as media and learning technology in higher education. In a broad sense it includes hardware, software, and human resources that can be used to enrich student learning experiences. The increasingly widespread use of the internet for educational purposes, especially in developed countries, shows that with this medium it is possible to hold a more effective teaching and learning process. Rosyadi and $\mathrm{Ilmi}^{12}$ find that technology is possibly applied in the process of Arabic learning. This is because e-learning has features teachers need in the teaching of four Arabic language skills. Iswanto ${ }^{13}$ adds that at least, there are innovations on the internet and e-learning.

Arabic e-learning contains a very broad meaning, so experts describe the definition of e-learning from various points of view. E-learning is a type of teaching and learning which allows the delivery of teaching materials to students using the Internet, Intranet or other computer network media. It is also an educational system that uses electronic applications to support teaching and learning using the internet, computer networks, and standalone computers ${ }^{14}$, one of them is Zoom. Zoom is an American communication technology company headquartered in San Jose, California. It provides video telephony and online chat services through a cloud-based peer-topeer software platform and is used for teleconferencing, telecommuting, distance education, and social relations. ${ }^{15}$

In connecting between technology and educational sector, Mirzajani, et. al. ${ }^{16}$ claim that educating in the classroom has changed with the coordination of ICT. The incorporation of ICT in learning activities is seen as a significant technique to expand the viability of the educating learning measure. Scientists previously investigated the

10 Roida Pakpahan and Yuni Fitriani, "Analisa Pemanfaatan Teknologi Informasi Dalam Pembelajaran Jarak Jauh Di Tengah Pandemi Virus Corona Covid-19", Journal of Information System, Applied, Management, Accounting and Research, [S.1.], Vol. 4, No. 2, 2020, 30-36.

11 Paulina Pannen, "Integrating technology in teaching and learning mathematics", Southeast Asian Mathematics Education Journal, Vol. 5, No. 1, 2015.

12 Faiq Ilham Rosyadi and Munaya Ulil Ilmi. "E-Learning: An Implementation for Arabic Learning During the Covid-19 Pandemic", Alsuniyat: Jurnal Penelitian Babasa, Sastra, dan Budaya Arab, Vol. 4, No. 1, 2021, 47-57.

13 Rahmat Iswanto, "Pembelajaran Bahasa Arab dengan Pemanfaatan Teknologi", Arabiyatuna Jurnal Bahasa Arab, Vol. 1, No. 2, 2017.

14 Rahmat Iswanto, "Pembelajaran Bahasa Arab dengan Pemanfaatan Teknologi", Arabiyatuna Jurnal Bahasa Arab, Vol. 1, No. 2, 2017.

15 Akhsanan and Ahmadi Muhammadiyah, "Model Belajar dan Pembelajaran Bahasa Arab Generasi Milenial”, Jurnal Bahasa Arab dan Pendidikan Bahasa Arab, Vol. 1, No. 2, 2020.

16 Hassan Mirzajani, Mahmud Rosnaini, Ayub Ahmad Fauzi Mohd, and Su Luan Wong, "Teachers' Acceptance of ICT and Its Integration in the Classroom", Quality Assurance in Education, Vol. 24, No. 1, 2016, 26-40. 


\section{Arabiyât Jurnal Pendidikan Bahasa Arab dan Kebahasaaraban, 8 (2), 2021}

utilization of ICT in the classroom. They have shown that coordinating ICT helps educator to build up understudies' capability in instructing. ${ }^{17}$ Incorporating ICT can be a medium to encourage the learning cycle. Moreover, ICT has changed as a fundamental structure block in the general public of this problematic 4.0 time, especially during Covid 19 pandemic.

However, as advised by Kucirkova et al., ${ }^{18}$ the viability of ICT use in instructing depends on the educator's innovativeness to oversee and to make intriguing learning exercises for students. Educators need to learn and alter how to oversee learning conduct diversely as they incorporate ICT in educating, thus skills of educator are important here. Several factors need to consider whilst enforcing online learning. Teachers, students and stakeholders to make the online learning occurred as planned.

Dwiono, Rochsantiningsih, and Suparno ${ }^{19}$ have targeted at the significance of instructors who have certificate/qualification on coaching ICT integration. However, the absence of instructor preparing in PC aptitudes is a significant issue which has been very much reported. ${ }^{20}$ Without adequate preparing to coordinate ICT in teaching for the instructor, there might be a misorigination of how ICT is being utilized by educators in learning for students in their study, in the end, it will impact the nature of instructing. Without a high skill to utilize ICT, we ought not expect instructors on incorporating ICT in their expert practices to be ideal. ${ }^{21}$

Therefore, the novelty of this paper discusses on students' difficulty in studying online, especially in studying TM which is not available yet in the literature review. We chose TM because it is a unique course offered in Arabic department in University X, and the lecturer used Zoom as the medium. To this end, the present study aimed to fill the gap in the literature review, on technology use and that TM. This paper becomes significant as there have been closed educational institution due to the Covid-19 pandemic and have moved to online learning. This paper could give some insights to any educational stakeholders

17 Nur A. Drajati, Lynde Tan, Sri Haryati, Dewi Rochsantiningsih, and Hasan Zainnuri, "Investigating English language teachers in developing TPACK and multimodal literacy", Indonesian Journal of Applied Linguistics, 2018, 575-582.

18 Rossie Flewitt and Natalia Kucirkova, "Touching the Virtual, touching the real: iPads and enabling literacy for students experiencing disability", Australian Journal of Language and Literacy, Vol. 37 No. 2, 2014.

19 Rija Dwiono, Dewi Rochsatiningsih, dan Suparno. "Investigating the Integration Level of Information and Communication Technology (ICT) in the English Language Teaching", International Journal of Language Teacbing and Education, Vol. 2, No. 3, 2018.

20 Alastair A. Anderson, "Predictors of computer anxiety and performance in information systems", Computers in Human Behavior, Vol. 12, No. 1, 1996, 61-77.

${ }^{21}$ Pedro Brás, Guilhermina Lobato Miranda, and João Marôco, "Teachers and technology: A complicated relationship", GSTF Journal on Education (JEd), Vol. 1, No. 2, 2014, 1-11. 


\section{Arabiyât Jurnal Pendidikan Bahasa Arab dan Kebahasaaraban, 8 (2), 2021}

\section{Method}

Design of this research was qualitative descriptive. We choose qualitative is because this research understands social phenomena from the perspective of the human participants in the research. Descriptive qualitative research is a study designed to obtain information concerning the phenomenon. ${ }^{22}$ According to Moleong, ${ }^{23}$ descriptive research is a method of research which tries to portray and interpret the objects as in the fact. Thus, in this research descriptive, researchers conducted in the purpose of describing systematically about the fact on an online phenomenon of studying TM in a learning environment and characteristics of the Arabic department students of University $\mathrm{X}$ who live in a rural area. In this case the phenomenon was the activities of teaching and learning Arabic during pandemic Covid-19 which obliges students to do online.

The design consists of a stage to interviews as data collection method. A semi structured interview was conducted to nine students. The specific characteristics of participants are that the students live in remote areas in which the internet access is relatively limited. They took TM course in the $2^{\text {nd }}$ semester, and are Arabic department students of X University. This interview was carried in online mode. In this interview the researcher asked detail questions about the students' experiences in learning online. Moreover, challenges they faced using online platform were also quested. Respondents were also asked how their suggestion about online learning may add to better learning online for the next semester. A Miles and Huberman's model ${ }^{24}$ has been used to analyse the data. It consists of data reduction, data display, conclusion drawing.

Data analysis began by examining the available data sources from the interview, then data reduction by making abstractions (summary of the core) to become an information. The units were then compiled and last held the trusty of the data. Based on this process, the data can be interpreted and processed into research. Stages presentation of data is a set of structured information that gives the possibility of drawing conclusions and taking action.

\section{Result and Discussion}

Experiences of Arabic department students on studying TM course using the Zoom application

Below is the interview result. Table 1 depicts the experiences of students learning online TM:

22 Sugiono, Metode Penelitian Kuantitatif, Kualitatif, dan R \& D, (Bandung: Alfabeta, 2016).

${ }^{23}$ Lexy J. Moleong, Metodologi Penelitian Kualitatif, (Bandung: Remaja Rosyda Karya, 2006), 5.

24 Matthew B. Miles and Michael A. Huberman, "Qualitative data analysis: An expanded sourcebook", Sage, 1994. 


\section{Arabiyât Jurnal Pendidikan Bahasa Arab dan Kebahasaaraban, 8 (2), 2021}

Table 1. Experience of Arabic department students in learning the online tarkî́b course.

\begin{tabular}{|c|c|c|}
\hline & Results & Sources \\
\hline \multirow{5}{*}{$\begin{array}{l}\text { Online } \\
\text { learning } \\
\text { Experiences } \\
\text { before and } \\
\text { during at } \\
\text { pandemic }\end{array}$} & $\begin{array}{l}\text { 1. Online learning before the pandemic was only on Hadits } \\
\text { Tarbawi / Tafsir Tarbawi with GCR when the lecturer was } \\
\text { unable to attend. }\end{array}$ & M1- M9 \\
\hline & & M1- M9 \\
\hline & $\begin{array}{l}\text { 2. Previously the lecturer sent written material and sent } \\
\text { evaluation instruments to be answered, whereas now all } \\
\text { learning activities are online. }\end{array}$ & M1- M9 \\
\hline & $\begin{array}{l}\text { 3. Some of the applications used in learning during a } \\
\text { pandemic are WA, GCR, Google Meet and Zoom. And the } \\
\text { heaviest use of zoom is the TM course, where the entire } \\
\text { meeting uses the zoom in addition to the companion } \\
\text { application, WA and GCR. }\end{array}$ & $\begin{array}{l}\text { M2, M3, M4, } \\
\text { M5, M1 M6, } \\
\text { M7, M8, M9 }\end{array}$ \\
\hline & $\begin{array}{l}\text { 4. Respondents studied the use of the zoom application } \\
\text { from: }\end{array}$ & M1- M9 \\
\hline \multirow{3}{*}{$\begin{array}{l}\text { The } \\
\text { Impression Of } \\
\text { the TM } \\
\text { Material }\end{array}$} & $\begin{array}{l}\text { 1. (a) Students from pondok pesanteren and Madrasah } \\
\text { Aliyah are very familiar with the material in the TM course } \\
\text { but not as specific as in the course. }\end{array}$ & $\begin{array}{l}\text { M1, M2, M3, } \\
\text { M4, M5, M6, } \\
\text { M8, M9 }\end{array}$ \\
\hline & & M7 \\
\hline & $\begin{array}{l}\text { (b) High school graduate students are still very unfamiliar } \\
\text { with the content of TM courses }\end{array}$ & M1 M9 \\
\hline \multirow{4}{*}{$\begin{array}{l}\text { Lecturer } \\
\text { learning model } \\
\text { during online } \\
\text { learning } \\
\text { during the } \\
\text { covid period }\end{array}$} & $\begin{array}{l}\text { 1. The TM learning model is that at the first meeting of } \\
\text { each discussion, the presenter delivers papers and } \\
\text { discussions. Then proceed to the second meeting on each } \\
\text { discussion, additional explanation from the lecturer. }\end{array}$ & M1-M9 \\
\hline & $\begin{array}{l}\text { 2. During the pandemic, the portion of the use of Arabic as } \\
\text { an introduction to lectures was reduced. }\end{array}$ & M1-M9 \\
\hline & $\begin{array}{l}\text { 3. The explanation of the speaker when offline is in more } \\
\text { detail. }\end{array}$ & \\
\hline & $\begin{array}{l}\text { 4. (a) delivery of material from the presenters and lecturers } \\
\text { verbally without the obligation to use PPT. }\end{array}$ & $\begin{array}{l}\text { M1, M3, M5, } \\
\text { M6, M7 }\end{array}$ \\
\hline
\end{tabular}


(b) the presentation of material by the presenter using a M1-M9 PPT on class Initiative

Student

Response during Online learning during covid
1. The communication that is established is more rigid and M1-M9 cannot throw small jokes, rebuttals and direct statements about language content that is not understood.

2. Reducing the desire to ask questions and respond M1-M9 because the information conveyed is not well understood.

3. active participation during the discussion also decreased M1-M9

5. not free to express opinions because the zoom M1-M9 application system is Less friendly

6. The exposure to reative material is not comprehensive M1-M9 and the concentration during lectures is not optimal due to signal interference

For Arabic department students, online learning is certainly not something new because they have previously studied in a similar mode but with different applications and still emphasize face-to-face. Meanwhile, in the TM course they had to learn by switching from face-to-face to virtual face-to-face which has limitations. This is inseparable from the current conditions that force lecturers and students to adapt to the conditions and various policies that have been enacted. However, not all teachers and students are ready to face changes in the learning system during this pandemic, as pointed out by Morgan. $^{25}$ As a result, students face problems in terms of understanding during the learning process. One student faced difficulty due to the use of Zoom as one of the Synchronous type lecture platforms. Zoom in its use has not been able to protect the limitations of students who are in remote areas amid limited access and financial reach.

The students studied TM at the previous level, although the material being studied today is certainly more in-depth and developing. However, in general, this material itself is considered difficult, especially for those who have not studied it at all, as expressed by Fahrurrozi ${ }^{26}$ that teaching Arabic in Indonesia often have several barriers both linguistic and also nonlinguistic problems. One of the linguistic problems

${ }^{25}$ Hani Morgan, "Best Practices for Implementing Remote Learning during a Pandemic", The Clearing House: A Journal of Educational Strategies, Issues and Ideas, Vol. 93, No. 3, 2020, 135-141.

26 Aziz Fahrurozi, "Pembelajaran bahasa Arab, problematika dan solusinya", Arabiyat, Vol. 1, No. 2, 2014. 


\section{Arabiyât Jurnal Pendidikan Bahasa Arab dan Kebahasaaraban, 8 (2), 2021}

is in terms of syntax or linguistic structure, even though this material is one of the main materials to support language competence as a prospective teacher.

In conditions where learning cannot be taken face-to-face, plus the obstacles arise because of the character of the material itself, lecturers are required to be skilled in applying various ways to carry out online learning effectively, as claimed by Kaufmann and Vallade ${ }^{27}$. Although technically the use of the Zoom application in lectures is also equipped with the use of Google Classroom and WhatsApp, its utilization has not been maximized as a companion application. Both help with uploading material and technical coordination, and these two applications are very helpful in technically using Zoom as the main medium for lectures. This is because both have the various features and ease of use. Therefore, Google classroom and WhatsApp rank highest sequentially as media that are loved in helping the learning process, namely $77 \%$ and $66 \%$ of users, as indicated by the results of a research opinion poll conducted by Zhafira. ${ }^{28}$

The Zoom platform as the main media in TM lectures has created difficulty, besides the TM material character requires detailed explanation and guidance from the lecturer. TM characteristics contribute to the difficulty. The transfer of knowledge and information is not only from presentations delivered by students during discussion sessions, but also added by explanations and various exercises in applying the rules which are guided directly by lecturers at different times. This kind of learning model is helpful for students in terms of deepening material and developing knowledge, shown by the enthusiasm of students during lectures to discuss and ask various things related to the material they are learning.

It becomes different when learning TM is carried out online using the Zoom application. As Zoom is a synchronous training e-learning mode requires educators and students to access the internet simultaneously to carry out virtual face-to-face. At the same time, the presentation of material from both students and lecturers (that is not mandatory using PPT) becomes a less meaningful learning experience. This definitely affects the understanding of material by students. because presentations using a power point program can develop meaningful learning compared to verbal presentations alone. Pannen ${ }^{29}$ says, media and learning technology in higher education using hardware, software, and human resources can be used to enrich student learning experiences. The optimal use of the media will help the implementation of the

27 Renee Kaufmann, and Jessalyn I. Vallade, "Exploring connections in the online learning environment: student perceptions of rapport, climate, and loneliness", Interactive Learning Environments, 2020, 1-15.

28 Nabila Hilmy Zhafira, Yenny Ertika, and Chairiyaton Chairiyaton, "Persepsi mahasiswa terhadap perkuliahan daring sebagai sarana pembelajaran selama masa karantina covid-19", Jurnal Bisnis Dan Kajian Strategi Manajemen, 2020, 37-45.

29 Paulina Pannen, "Integrating technology in teaching and learning mathematics", Southeast Asian Mathematics Education Journal, Vol. 5, No. 1, 2015. 


\section{Arabiyât Jurnal Pendidikan Bahasa Arab dan Kebahasaaraban, 8 (2), 2021}

learning process more effectively. In line with Mirzajani's opinion, ${ }^{30}$ ICT is helpful to the learning acceptance process, and to build student abilities and encourage the learning cycle, as Drajati ${ }^{31}$ claimed.

The conditions of learning process with only one medium prove that lecturers are categorized as beginner in ICT. Utilising other media not only regulate the learning model but also help the limitations of users in using various service features when learning takes place by Zoom. This occurs due to the limited knowledge and ability of users to apply ICT in learning. Therefore, as stated by Kucirkova, ${ }^{32}$ the continuity of the use of ICT in teaching depends on the innovation of lecturers to supervise and make attractive learning. Thus, in this case, both students and lecturers, are required to have the ability and skills to use ICT such as simple Power Point tools, other virtual resources or the use of e-learning features in learning to help students achieve their goals. Dwiono et $\mathrm{al}^{33}$ emphasize the importance of instructors who have certificates/qualifications in fostering ICT integration in learning. However, the absence of instructors or special enrichment by study program managers or from universities who prepare media utilization skills, as written by Anderson. ${ }^{34}$, is a significant problem that has been widely complained of.

With this ICT skill, students will have provisions for optimal use both in certain workshops initiated by the institution and the lecturer themselves as the initiator of the use of the Zoom application with presentations using online power point. Bras Pedro ${ }^{35}$ says the current condition requires lecturers to try even harder to adapt their abilities to current demands. In addition, students also need to be more independent in studying the material in order that they can follow the ongoing online learning process more easily.

Other difficulties related to material delivery are also experienced by students. Students got used with lecturers who present material and give examples in real time in detail on the blackboard. When using Zoom, material and examples are only obtained through file that has been previously sent and added with verbal explanations during virtual face-to-face meetings. This becomes a problem for students due to the divided concentration because at the same time they have to open the material file on

30 Hassan Mirzajani, Rosnaini Mahmud, Ahmad Fauzi Mohd Ayub, and Su Luan Wong, “Teachers' Acceptance of ICT and Its Integration in the Classroom", Quality Assurance in Education, Vol. 24, No. 1, 2016, 26-40.

31 Nur A. Drajati, Lynde Tan, Sri Haryati, Dewi Rochsantiningsih, and Hasan Zainnuri, "Investigating English language teachers in developing TPACK and multimodal literacy", Indonesian Journal of Applied Linguistics, 2018, 575-582.

32 Rossie Flewitt, and Natalia Kucirkova, "Touching the Virtual, touching the real: iPads and enabling literacy for students experiencing disability", Australian Journal of Language and Literacy, Vol. 37 No. 2, 2014.

33 Rija Dwiono, Dewi Rochsatiningsih, dan Suparno, "Investigating the Integration Level of Information and Communication Technology (ICT) in the English Language Teaching", International Journal of Language Teaching and Education, Vol. 2, No. 3, 2018.

34 Alastair A Anderson, "Predictors of computer anxiety and performance in information systems", Computers in Human Behavior, Vol. 12, No. 1, 1996, 61-77.

35 Pedro Brás, Guilhermina Lobato Miranda, and João Marôco, "Teachers and technology: A complicated relationship", GSTF Journal on Education (JEd), Vol. 1, No. 2, 2014, 1-11. 


\section{Arabiyât Jurnal Pendidikan Bahasa Arab dan Kebahasaaraban, 8 (2), 2021}

the laptop but also listen to explanations via Zoom without using other visual media amid the limited signal in their respective areas. In addition, students were reluctant to put forward the interruption when the discussion was taking place, even though they did not really understand what was being said, especially for some terms or expressions in Arabic. This is surely different under normal circumstances. Limitations in the use of chat room features such as rising hands or suggesting instructions through chat rooms are channelled into this obstacle.

The lack of power of students when expressing opinions, debating and asking questions during lectures is also influenced by communication that is relatively more rigid than offline learning. Several obstacles resulted in a lecture agreement should be communicated again in an open forum. The limited chance to ask also makes students' passion and motivation decrease. This condition is contrary to the research conducted by Dorris Yadewani ${ }^{36}$ that there is an effect of the use of e-learning on student learning motivation and achievement.

In short, the preparation before providing learning services is one of the determining factors in learning success, especially in online learning where there is a gap between learner and educator. TM lecturer must know the principles of learning and how students learn. The delivery tool is not a determining factor for the quality of learning, but rather the course design determines the effectiveness of learning. One of the reasons for choosing a learning strategy is to promote meaningful learning. Thus the effectiveness of learning or not can be identified through the behaviors between learners and educators and how learners respond to what is conveyed by learners.

Moreover, there is the lack of ability among the participants to argue, respond and ask questions via Zoom. In offline, each discussion participant can ask questions that are not understood linguistically during the presentation or ask directly without any technical problems. Using Zoom, long distance communication and discomfort become uncomfortable experiences felt by students, and at the same time light communication as a release of boredom cannot be done directly. This is in line with the research conducted by Reni Wijaya, Mustika Lukman, and Dorris Yadewani ${ }^{37}$ that lecturers and students who learn by using e-learning, experienced difficulties including lack of communication and socialization between students and lecturers.

Based on the explanation above, students studying TM courses online using the Zoom application experienced problems, especially those who live in border or remote areas. The lack of visual interaction between students and material becomes a difficulty for them, especially when they are not free to express their opinions with a limited sense of discomfort for interruption during ongoing discussions. This circumstance raises reluctance for some students to actively involve.

36 Dorris Yadewani, "Pengaruh Pemanfaatan E-Learning Dan Motivasi Belajar Terhadap Prestasi Belajar Mahasiswa Amik Jayanusa Padang Studi Kasus AMIK Jayanusa Padang”, Jurnal J-Click, 2016.

${ }^{37}$ Reni Wijaya, Mustika Lukman, and Dorris Yadewani, "Dampak Pandemi Covid19 Terhadap Pemanfaatan E Learning”, Jurnal Dimensi, Vol. 9, No. 2, 2020, 307-322. 


\section{Arabiyât Jurnal Pendidikan Bahasa Arab dan Kebahasaaraban, 8 (2), 2021}

2. Challenges associated with Arabic department students studying the TM course using Zoom in remote areas.

Table below describes the challenges faced by Arabic department students:

Table 2. Challenges faced by students in Arabic department learning the subject of TM in Remote areas

\begin{tabular}{|c|c|c|}
\hline $\begin{array}{l}\text { Research } \\
\text { Question }\end{array}$ & Results & Sources \\
\hline \multirow[t]{3}{*}{$\begin{array}{l}\text { Network / } \\
\text { Provider used }\end{array}$} & $\begin{array}{l}\text { 1. A strong provider in the regions is Telkomsel with a } \\
\text { higher price }\end{array}$ & MI-M9 \\
\hline & $\begin{array}{l}\text { 2. The majority of students use private providers whose } \\
\text { networks are no better than government providers. }\end{array}$ & $\begin{array}{l}\text { M2, M3, M4, } \\
\text { M5, M6, M8, } \\
\text { M9 }\end{array}$ \\
\hline & 3. Use wifi but if the lights go out, wifi is also off & M1, M7 \\
\hline \multirow{6}{*}{$\begin{array}{l}\text { Technical } \\
\text { constraints } \\
\text { faced by } \\
\text { students when } \\
\text { taking online. } \\
\text { Lectures } \\
\text { Using zoom } \\
\text { are: }\end{array}$} & 1. The signal is not stable & MI-M9 \\
\hline & $\begin{array}{l}\text { 2. Internet usage capacity during the day is overloaded, both } \\
\text { for online learning and just playing }\end{array}$ & $\begin{array}{l}\text { M2, M4, M5, } \\
\text { M7, M9 }\end{array}$ \\
\hline & 3. Blackout resulting in the outage of the signal in the area & $\begin{array}{l}\text { M1, M3, M4, } \\
\text { M6, M8 }\end{array}$ \\
\hline & $\begin{array}{l}\text { 4. Free zoom will automatically stop every } 45 \text { minutes and } \\
\text { have to log back in for follow-up sessions which are often } \\
\text { hampered even though the signal is still good. }\end{array}$ & MI-M9 \\
\hline & 5. The device has a problem & M7, M9 \\
\hline & $\begin{array}{l}\text { 6. Using google form with a time limit for UTS problems } \\
\text { when the signal in the area is lost. }\end{array}$ & M4 \\
\hline \multirow{4}{*}{$\begin{array}{l}\text { Non-technical } \\
\text { obstacles } \\
\text { faced by } \\
\text { students when } \\
\text { taking online } \\
\text { lectures are: }\end{array}$} & $\begin{array}{l}\text { 1. Quota prices for providers with stronger networks are } \\
\text { relatively expensive }\end{array}$ & MI-M9 \\
\hline & 2. Interesting notifications when learning takes place & M8, M9 \\
\hline & 3. The quota used is larger & $\begin{array}{l}\text { M1, M3, M4, } \\
\text { M5, M6, M7, } \\
\text { M9 }\end{array}$ \\
\hline & 4. Less conducive learning atmosphere & M3, M4, M5, \\
\hline
\end{tabular}


Ara6iyât Jurnal Pendidikan Bahasa Arab dan Kebahasaaraban, 8 (2), 2021

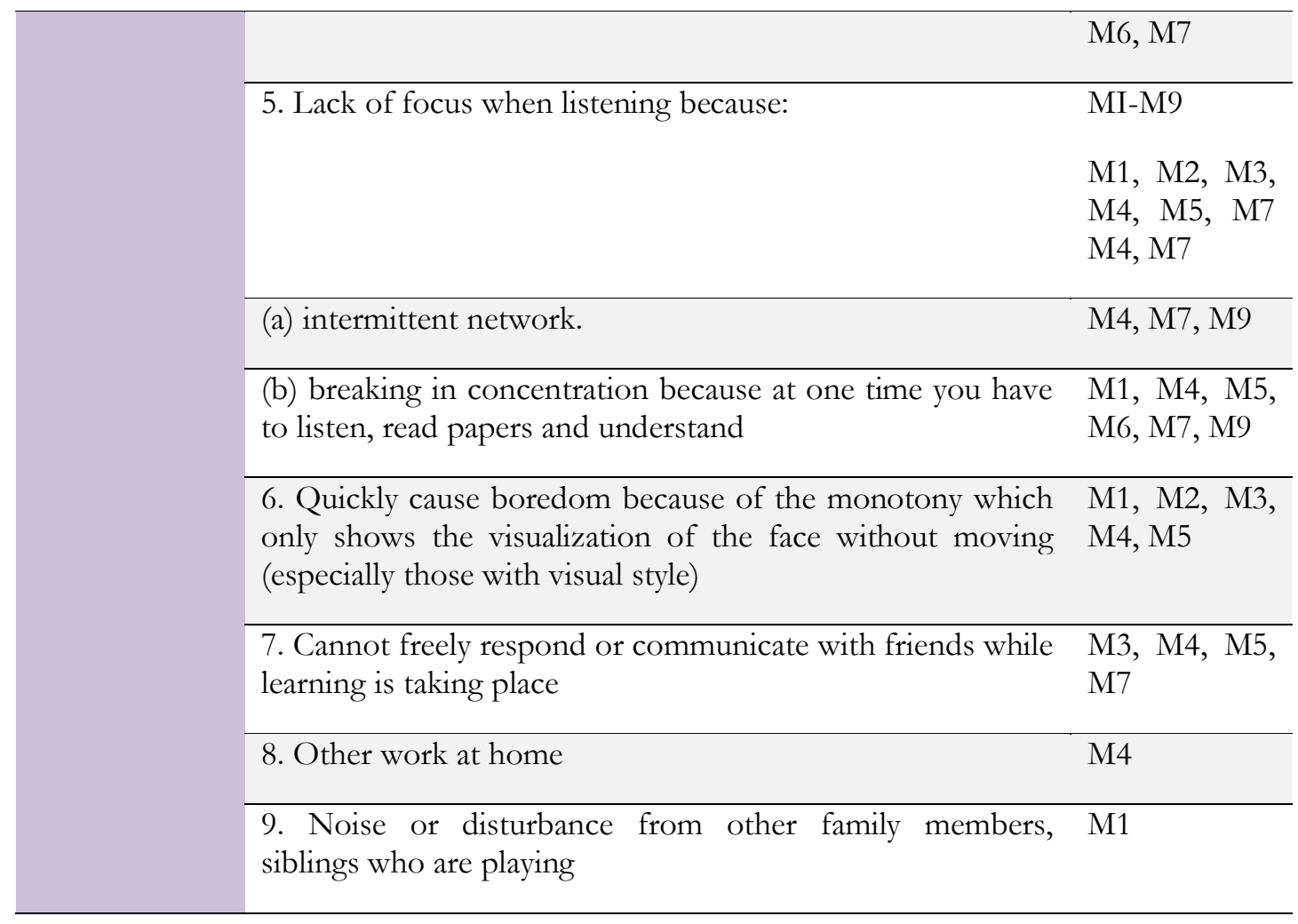

The distance learning model is a new policy implemented at campus, and cannot be separated from the various obstacles, both technically and non-technically. Most of the technical constraints were related to signal interference and monotonous presentation of lecture materials, while non-technical constraints were related to financial, psychological, communication and social issues.

The main disturbance and obstacle for students living in remote and border areas is an unstable signal due to inadequate network. The same thing was also expressed by Hastini, Fahmi and Lukito, ${ }^{38}$ who state that learning via the internet was difficult to do in certain areas with inadequate networks. In addition, access to information is hampered by signal because some students are in areas with weak signal strength as stated by Patiwi. ${ }^{39}$ Overall, Permana and Daryati ${ }^{40}$ state that distance learning in border or remote areas does not relatively run well with unstable internet networks.

${ }^{38}$ Lasti Yossi Hastini, Rahmi Fahmi, and Hendra Lukito, “Apakah Pembelajaran Menggunakan Teknologi dapat Meningkatkan Literasi Manusia pada Generasi Z di Indonesia?”, Jurnal Manajemen Informatika (JAMIKA), Vol. 10, No. 1, 2020, 12-28.

39 Ericha Windhiyana Pratiwi, "Dampak Covid-19 Terhadap Kegiatan Pembelajaran Online Di Sebuah Perguruan Tinggi Kristen Di Indonesia”, Perspektif Ilmu Pendidikan, Vol. 34, No. 1, 2020, 1-8.

40 Gerry Krista Permana, and Daryati Daryati, "Persepsi Siswa dan Guru Terhadap Pelaksanaan Pembelajaran Berbasis E-Learning Di SMK Negeri 4 Jakarta", Jurnal Pensil: Pendidikan Teknik Sipil, Vol. 2, No. 2, 2013, 111-117. 


\section{Arabiyât Jurnal Pendidikan Bahasa Arab dan Kebahasaaraban, 8 (2), 2021}

This is exacerbated by the use of the Zoom application which is relatively heavier and real-time learning without data backup in the form of learning recordings as anticipation for students who cannot fully participate in learning. Not only the signal limitations, but the difficulty when using Free Zoom which automatically stops every 45 minutes also hampered, even though the signal is still good. This is due to the server being down or having difficulty re-accessing the applications used because they are time-limited and can be accessed free of charge. ${ }^{41}$

In addition to network constraints, students often get bored because the presentation of material is monotonous. It only displays facial visualization without an attractive presentation. As a result, other notifications that appear on student flat screens or other interesting video content are more of their attention. According to Rusdiana and Nugroho ${ }^{42}$ this condition certainly requires teachers to prepare a more attractive learning mode by optimizing various learning support devices. Even though it was not very familiar before, but guidance on conditions forced teachers to do more than offline learning. Teacher readiness certainly greatly affects success in learning.

Due to the technical constraints mentioned above, the communication is not fluent and can disturb student concentration. It causes anxiety if students cannot understand and follow lessons such as in offline learning. Moreover, tasks that pile up with inadequate environmental conditions to support learning and online learning in real time mode require students to listen, read papers and understand at one time, making students feel depressed. In addition, the use of Google Forms with time limits such as offline learning, needs to be reviewed with the technical obstacles faced because students cannot submit assignments on time.

Like a problem stated by Morgan, ${ }^{43}$ there is another non-technical obstacle that hinders current distance learning, namely the internet prices for stronger network providers are relatively expensive. This problem adds to new spending for students who their parents affected by pandemic and their family income may experience decreased.

Another issue was raised by Purwanto, Pramono, Asbari, Santoso, Wijayanti, Hyun and Putri. ${ }^{44}$ Other works at home such as helping parents financially makes the learning becomes more problematic. This happens mostly for those students with financial limitations. The impact of the Covid-19 pandemic has an impact on the learning process of students who learn from home.

${ }^{41}$ Reni Wijaya, Mustika Lukman, and Dorris Yadewani, "Dampak Pandemi Covid19 Terhadap Pemanfaatan E Learning”, Jurnal Dimensi, Vol. 9, No. 2, 2020, 307-322.

42 Emmilia Rusdiana and Arianto Nugroho, "Respon Mahasiswa Pada Pembelajaran Daring Bagi Mahasiswa Mata Kuliah Pengantar Hukum Indonesia UNESA”, Integralistik, Vol. 31, No. 1, 2020, 1-12.

43 Hani Morgan, "Best Practices for Implementing Remote Learning during a Pandemic", The Clearing House: A Journal of Educational Strategies, Issues and Ideas, Vol. 93, No. 3, 2020, 135-141.

${ }_{44}$ Agus Purwanto, Rudy Pramono, Masduki Asbari, Choi Chi Hyun, Laksmi Mayesti Wijayanti, and Ratna Setyowati Putri, "Studi Eksploratif Dampak Pandemi COVID-19 Terhadap Proses Pembelajaran Online di Sekolah Dasar", EduPsyCouns: Journal of Education, Psychology and Counseling, Vol. 2, No. 1, 2020, 1-12. 


\section{Arabiyât Jurnal Pendidikan Bahasa Arab dan Kebahasaaraban, 8 (2), 2021}

Non-technical matter in online learning with this Zoom application is about communication between lecturers and students. There is less cooperative and responsive, especially for those students who experience limited access. This poor communication between lecturers and students, as well as students and students, is an obstacle in realizing effective online learning. ${ }^{45}$ In addition, the inexistence of positive feedback from the teacher and the ability to communicate among students also makes the online learning process more terrible for students. This problem is not only experienced for learning that uses Zoom, but also other e-learning applications. ${ }^{46}$

3. The way Arabic department students solve problems while learning the online TM course using the Zoom application.

The last table shows how students solve their online TM learning.

\begin{tabular}{|c|c|c|}
\hline $\begin{array}{l}\text { Research } \\
\text { Question }\end{array}$ & Results & Sources \\
\hline \multirow{4}{*}{$\begin{array}{l}\text { Efforts made } \\
\text { by respondents } \\
\text { when they } \\
\text { encountered } \\
\text { difficulties in } \\
\text { learning }\end{array}$} & $\begin{array}{l}\text { 1. Take an active role during group discussion sessions and } \\
\text { lecturer explanation sessions }\end{array}$ & M7, M9 \\
\hline & $\begin{array}{l}\text { 2. Ask friends or presenters after the learning session ends } \\
\text { through WA media }\end{array}$ & M1-M9 \\
\hline & 3. Search for additional material on the internet & $\begin{array}{l}\text { M1, M7, M8, } \\
\text { M9 }\end{array}$ \\
\hline & $\begin{array}{l}\text { 4. Reopening the files shared by friends who better } \\
\text { understand the material }\end{array}$ & M5, M6, M7 \\
\hline \multirow{3}{*}{$\begin{array}{l}\text { Respondent's } \\
\text { efforts whwn } \\
\text { it comes to } \\
\text { learning } \\
\text { difficulties, } \\
\text { when the } \\
\text { network is } \\
\text { unstable }\end{array}$} & $\begin{array}{l}\text { 1. Looking for the best network location point, for example } \\
\text { to the } 2^{\text {nd }} \text { Floor, outside the room even to neighbors or to a } \\
\text { family place that has Wifi. }\end{array}$ & $\begin{array}{l}\text { M1, M2, M3, } \\
\text { M7, M9 }\end{array}$ \\
\hline & $\begin{array}{l}\text { 2. Contact the class president to confirm that the network } \\
\text { is not good }\end{array}$ & $\begin{array}{l}\text { M1, M4, M5, } \\
\text { M7 }\end{array}$ \\
\hline & $\begin{array}{l}\text { 3. Some others just surrender and remain in their original } \\
\text { location while Waiting for the signal to appear again }\end{array}$ & M3, M6, M8 \\
\hline
\end{tabular}

45 Dwi Hardani Oktawirawan. "Faktor Pemicu Kecemasan Siswa dalam Melakukan Pembelajaran Daring di Masa Pandemi Covid-19”, Jurnal Ilmiah Universitas Batanghari Jambi, Vol. 20, No. 2, 2020, 541-544.

${ }^{46}$ Reni Wijaya, Mustika Lukman, and Dorris Yadewani, "Dampak Pandemi Covid19 Terhadap Pemanfaatan E Learning”, Jurnal Dimensi, Vol. 9, No. 2, 2020, 307-322. 


\section{Arabiyât Jurnal Pendidikan Bahasa Arab dan Kebahasaaraban, 8 (2), 2021}

\begin{tabular}{ll}
$\begin{array}{l}\text { Suggestions } \begin{array}{l}\text { for smooth } \\
\text { learning }\end{array} \\
\text { the WA group } 2 .\end{array}$ & $\begin{array}{l}\text { 1. Save the recording of the meeting and then share it with } \\
\text { M7, M2, M4, }\end{array}$ \\
\cline { 2 - 3 } $\begin{array}{l}\text { 2. Provide an opportunity to ask questions to those who are } \\
\text { less active }\end{array}$ & $\begin{array}{l}\text { M3, M5, M6, } \\
\text { M7 }\end{array}$ \\
\hline $\begin{array}{l}\text { 3. Open communication even during explanation offline } \\
\text { meetings }\end{array}$ & M1-M9 \\
\hline 4. Make a compelling PPT presentation & M7, M9
\end{tabular}

Obstacles to distance learning with the various applications used must be resolved. Especially if the application used greatly hinders the learning process. Technically, getting a good access point is an alternative to dispel the obstacles, even though there are still students who give up without doing anything and just waiting. The unmotivated students need more attention of the teachers and the family environment.

In addition, studying independently by repeating the lessons presented by the facilitator as well as discussing with friends outside of lectures is a solution for current students. With this solution, the independence of students plays a role in creating the success of online learning.

To reduce these difficulties, researchers offered to respondents for smooth learning for lecturers and students. For instance, for further online learning for any subjects, the advice is as follows.

Lecturers keep the recording of the meeting and then share it to their students in the WA group. The results of the meeting are recorded and shared to the WAG so that students who are constrained by signals can still listen and watch the lecture fully. Alternatively, the teacher will provide the opportunity to ask those who are less active. Other suggestions, since most students are used to seeing and hearing their lecturer, video-based mini lessons can make a creative difference during online teaching. Students tend to prefer video lessons and demonstrations, which can be created using a cell phone camera or direct software.

Students are technically informed about the use of the application, by making some technical class agreements to avoid harming students. For materials, lecture materials and references can be shared on GC. To avoid disconnection, teachers can use virtual face-to-face applications that do not have to be disconnected, such as Google Meet. This situation could help make conditions more comfortable, allowing students to ask each other or give responses, either directly or through chat rooms.

As for the communication aspect, to increase interaction, the teacher provides the opportunity to raise objections or interruptions during the presentation by mutual agreement, and maximize the chat room facilitated by the moderator. The teacher can maximize the WAG if when obstacles during the meeting or evaluation occur. The 


\section{Arabiyât Jurnal Pendidikan Bahasa Arab dan Kebahasaaraban, 8 (2), 2021}

teacher provides another alternative if using the application for a limited evaluation time or extending the evaluation period provided that it still produces outputs. Students are also required to share the PPT slides during the presentation, if possible while presenting an example of one section until they fully understand it as offline learning.

In delivering material, it does not have to be rigid by only meeting face to face in cyberspace but can be accompanied by movements or writing on the blackboard to facilitate visual or kinesthetic learning styles. Lecturers are asked to provide motivation to learn like in offline mode.

For students, they can buy a provider package with a strong signal specifically for lectures that often use virtual face-to-face, the rest can return to cheaper providers. For students who are affected by a lot of bad signals, it is advisable to look for the strongest points before lectures take place even though they have to move locations to maximize learning.

Papers can be shared the day before the meeting, while slides can be shared during the presentation. Students prepare additional material in addition to material distributed by speakers and lecturers thus students can gain initial experience and easily connect with the latest information. In face-to-face virtual meetings, lecturers can also maximize the delivery of material via YouTube which can be accessed at any time and repeated and discussed on learning platforms such as GC or WAG.

\section{Conclusion}

In summary, it is difficult for Arabic department students to use technology. The implementation of e-learning, no matter how sophisticated the technology used, has not been able to replace the implementation of face-to-face learning because this conventional interaction methods are still much more effective than online learning. The students find it difficult to use the online platform affect the level of understanding in the TM course. Those difficulties are limitations in the internet accessibility, hardware, software, communication and financial often become problems in maximizing online learning resources. However, the students are able to overcome their online learning problems by creating higher motivation to study, such as searching additional material in the internet and asking friend for helps. Lecturers at Arabic department are highly expected to understand the students' circumstances and have made a small research before implementing online learning with specific platforms and know how to anticipate when problems occur during the teaching and learning. Campuses can help lecturers make plans before implementing online education to avoid students fall behind and are disadvantaged. This is to realize the benefits of quality online education instead. However, the ongoing research about other subjects and using other online platform than Zoom is encouraged, in order to widen research topics.[] 


\section{Arabiyât Jurnal Pendidikan Bahasa Arab dan Kebahasaaraban, 8 (2), 2021}

\section{REFERENCES}

Akhsan and Ahmadi Muhammadiyah. "Model Belajar dan Pembelajaran Bahasa Arab Generasi Milenial", Jurnal Bahasa Arab dan Pendidikan Bahasa Arab, Vol. 1, No. 2,2020 .

Anderson, Alastair A. "Predictors of computer anxiety and performance in information systems", Computers in Human Behavior, Vol. 12, No. 1, 1996.

Brás, Pedro., Guilhermina Lobato Miranda, and João Marôco. "Teachers and technology: A complicated relationship", GSTF Journal on Education (JEd), Vol. 1, No. 2, 2014.

Darmadi, Hamid. "Tugas, Peran, Kompetensi, dan Tanggung Jawab Menjadi Guru Profesional”, Jumal Edukasi, Vol. 13, No. 2, 2015.

Drajati, Nur A., Lynde Tan, Sri Haryati, Dewi Rochsantiningsih, and Hasan Zainnuri. "Investigating English language teachers in developing TPACK and multimodal literacy", Indonesian Journal of Applied Linguistics, Vol. 7, No. 3, 2018.

Fahrurrozi, Aziz. "Pembelajaran bahasa Arab, problematika, dan solusinya", Arabiyat, Vol. 1, No 2, 2014.

Flewitt, Rossie., and Natalia Kucirkova. "Touching the Virtual, touching the real: iPads and enabling literacy for students experiencing disability", Australian Journal of Language and Literacy, Vol. 37, No. 2, 2014.

Hastini, Lasti Yossi., Rahmi Fahmi, and Hendra Lukito. "Apakah Pembelajaran Menggunakan Teknologi dapat Meningkatkan Literasi Manusia pada Generasi Z di Indonesia?", Jurnal Manajemen Informatika (JAMIKA), Vol. 10, No. 1, 2020.

Iswanto, Rahmat. "Pembelajaran Bahasa Arab dengan Pemanfaatan Teknologi", Jurnal Bahasa Arab, Vol. 1, No. 2, 2017.

Kaufmann, Renee., and Jessalyn I. Vallade. "Exploring connections in the online learning environment: student perceptions of rapport, climate, and loneliness", Interactive Learning Environments, 2020.

Mezzacappa, Dale., and Avi Wolfman-Arent. "Hite clarifies ban on 'remote instruction' during shutdown", Philadelphia Public School Notebook, https://thenotebook.org/articles/2020/03/18/philly-schools-forbid-remoteinstruction-during-shutdown-for-equity-concerns/ accessed on 2020.

Miles, Matthew B., and A. Michael Huberman. Qualitative data analysis: An expanded sourcebook. Sage, 1994.

Mirzajani, Hassan., Rosnaini Mahmud, Ahmad Fauzi Mohd Ayub, and Su Luan Wong. “'Teachers' acceptance of ICT and its integration in the classroom", Quality Assurance in Education, Vol. 24, No. 1, 2016.

Moleong, Lexy J. Metodologi Penelitian Kualitatif. Bandung: Remaja Rosyda Karya, 2006. 5. 


\section{Arabiyât Jurnal Pendidikan Bahasa Arab dan Kebahasaaraban, 8 (2), 2021}

Morgan, Hani. "Best Practices for Implementing Remote Learning during a Pandemic", The Clearing House: A Journal of Educational Strategies, Issues and Ideas, Vol. 93, No. 3, 2020.

Oktawirawan, Dwi Hardani. "Faktor Pemicu Kecemasan Siswa dalam Melakukan Pembelajaran Daring di Masa Pandemi Covid-19", Jurnal Ilmiah Universitas Batanghari Jambi, Vol. 20, No. 2, 2020.

Pakpahan, Roida., and Yuni Fitriani. "Analisa Pemanfaatan Teknologi Informasi Dalam Pembelajaran Jarak Jauh di Tengah Pandemi Virus Corona Covid-19”, Journal of Information System, Applied, Management, Accounting and Research, Vol. 4, No. 2, 2020.

Pannen, Paulina. "Integrating technology in teaching and learning mathematics", Southeast Asian Mathematics Education Journal, Vol. 5, No. 1, 2015.

Permana, Gerry Krista., and Daryati. "Persepsi Siswa dan Guru Terhadap Pelaksanaan Pembelajaran Berbasis E-Learning Di SMK Negeri 4 Jakarta", Jurnal Pensil: Pendidikan Teknik Sipil, Vol. 2, No. 2, 2013.

Pratiwi, Ericha Windhiyana. "Dampak Covid-19 Terhadap Kegiatan Pembelajaran Online Di Sebuah Perguruan Tinggi Kristen Di Indonesia", Perspektif Ilmu Pendidikan, Vol. 34, No. 1, 2020.

Purwanto, Agus., Rudy Pramono, Masduki Asbari, Choi Chi Hyun, Laksmi Mayesti Wijayanti, and Ratna Setyowati Putri. "Studi Eksploratif Dampak Pandemi COVID-19 Terhadap Proses Pembelajaran Online di Sekolah Dasar", EduPsyCouns: Journal of Education, Psychology and Counseling, Vol. 2, No. 1, 2020 .

Rija, Dwiono Dwiono., Dewi Rochsatiningsih, and Suparno. "Investigating the Integration Level of Information and Communication Technology (ICT) in the English Language Teaching", International Journal of Language Teaching and Education, Vol. 2, No. 3, 2018.

Rosyadi, Faiq Ilham., and Munaya Ulil Ilmi. "E-Learning: An Implementation for Arabic Learning During the Covid-19 Pandemic", Alsuniyat: Jurnal Penelitian Bahasa, Sastra, dan Budaya Arab, Vol. 4, No. 1, 2021.

Rosyidi, Abdul Wahab. "Peningkatan Kualitas Pengajar Bahasa Arab Sebagai Upaya Meningkatkan Standar Mutu Pembelajaran Bahasa Arab", Jurnal Ilmiah Peuradeun, Vol. 2, No. 3, 2014.

Rusdiana, Emmilia., and Arianto Nugroho. "Respon Mahasiswa Pada Pembelajaran Daring Bagi Mahasiswa Mata Kuliah Pengantar Hukum Indonesia UNESA", Integralistik, Vol. 31, No. 1, 2020.

Sugiono. Metode Penelitian Kuantitatif, Kualitatif, dan R \& D. Bandung: Alfabeta, 2016.

Tim Penyusun Badan Pusat Statistik, "Data Sensus Pendidikan", accessed on https://www.bps.go.id/subject/28/pendidikan.html 
Ara6iyât Jurnal Pendidikan Bahasa Arab dan Kebahasaaraban, 8 (2), 2021

UNESCO, "COVID-19 Educational Disruption and Response, 2020", [online] Available at: https://en.unesco.org/covid19/educationresponse

Wijaya, Reni., Mustika Lukman, and Dorris Yadewani. "Dampak Pandemi Covid19 Terhadap Pemanfaatan E Learning”, Jurnal Dimensi, Vol. 9, No. 2, 2020.

Yadewani, Dorris. "Pengaruh Pemanfaatan E-Learning Dan Motivasi Belajar Terhadap Prestasi Belajar Mahasiswa Amik Jayanusa Padang Studi Kasus AMIK Jayanusa Padang", Jurnal J-Click, Vol. 3, No. 2, 2016.

Zhafira, Nabila Hilmy., Yenny Ertika, and Chairiyaton Chairiyaton. "Persepsi mahasiswa terhadap perkuliahan daring sebagai sarana pembelajaran", Jumal Bisnis Dan Kajian Strategi Manajemen, Vol. 4, No. 1, 2020. 